\title{
TOWARD U.S. ACCEPTANCE OF THE INTERNATIONAL CRIMINAL COURT
}

\author{
BRUCE BROOMHALL*
}

\section{INTRODUCTION}

Since the Rome Diplomatic Conference was concluded in July 1998 with the adoption of the Rome Statute of the International Criminal Court (the "ICC"), the United States has been seeking accommodation of what it calls "fundamental concerns" with the final text. ${ }^{2}$ This effort has most recently taken place through the meetings of the ICC Preparatory Commission ("PrepCom").

The endeavor has been a frustrating one for the United States. Unable to offer credible "carrots," decisive "sticks," or viable legal arguments, the United States finds itself on "a lonely legal ledge," ${ }^{4}$ able neither to go forward nor to

Copyright (c) 2001 by Bruce Broomhall

This article is also available at http://www.law.duke.edu/journals/64LCPBroomhall.

* Senior Coordinator, International Justice Program, Lawyers Committee for Human Rights; Ph.D. Candidate, King's College London School of Law.

The author participated as an NGO (non-governmental organization) representative at the Rome Diplomatic Conference, and has since participated in several sessions of the Preparatory Commission, including as Team Leader for Part 2 (Jurisdiction, Admissibility, Applicable Law) of the NGO Coalition for an International Criminal Court. This essay is based largely on impressions gained through the author's participation in the PrepCom process and on discussions with NGO representatives and government delegates. Views expressed are solely those of the author.

1. U.N. Doc. A/Conf.183/9 (1998) [hereinafter the Rome Statute], as corrected by the procésverbaux of Nov. 10, 1998 and July 12,1999. For a survey of efforts to establish an international criminal court up to and through the Rome Conference, see M. CHERIF BASSIOUNI, THE STATUTE OF THE INTERNATIONAL CRIMINAL COURT: A DOCUMENTARY HISTORY (1998). For the negotiating dynamics of the Conference, see Philippe Kirsch \& John T. Holmes, The Rome Conference on an International Criminal Court: The Negotiating Process, 93 A.J.I.L. A detailed examination of the negotiation of various parts of the statute is found in THE INTERNATIONAL CRIMINAL COURT: ISSUES, NEGOTIATIONS, RESUlts (Roy S. Lee ed., 1999). An article-by-article explication of the statute is found in COMMENTARY ON THE ROME STATUTE OF THE INTERNATIONAL CRIMINAL COURT: OBSERVERS' Notes, ARTICLE By ARTIClE (Otto Triffterer ed., 1999). (1999).

2. David J. Scheffer, The United States and the International Criminal Court, 93 A.J.I.L. 12, 21

3. The PrepCom was established by General Assembly Resolution 53/105, pursuant to Resolution F of the Final Act of the United Nations Diplomatic Conference of Plenipotentiaries on the Establishment of an International Criminal Court, U.N. Doc. A/CONF.183/10 (1998). The task of the PrepCom is to negotiate subsidiary instruments (in particular the Rules of Procedure and Evidence and the Elements of Crimes, which were adopted in draft on June 30, 2000, see U.N. Doc. PCNICC/2000/INF/3/Add.1 (July 12, 2000) and PCNICC/2000/INF/3/Ad.2 (July 6, 2000)) in addition to "discuss ways to enhance the effectiveness and acceptance of the Court," see U.N. Doc. A/Res/53/105 II 4 (1999). The latter language was inserted in order to give the United States the opportunity to air its concerns through the PrepCom process.

4. Ruth Wedgwood, Courting disaster: The U.S. Takes a Stand, FOR. SERV. J., Mar. 2000, at 34, 39. 
step back. Asking for concessions it cannot win in a process it can neither leave nor oppose, the United States has so far resisted coming to terms with the limits of its ability to control the ICC process. It has also resisted the recognition that its reasons to support the ICC far outweigh its reasons to oppose it. That its eventual support for the ICC (if only as a non-party) is nonetheless highly likely is argued below.

\section{II}

\section{The U.S. Negotiating Aim And "Flaws" in the Rome StATUTE}

When it refers to "flaws" in the Rome Statute, the United States refers to the ICC's ability to exercise jurisdiction over the nationals of non-party states to the statute without the consent of those states. ${ }^{6}$ The U.S. government sees in this the possibility of U.S. personnel being investigated for war crimes by an international tribunal. That the court would be able to do so only when the national of the non-party state is suspected on reasonable grounds of committing genocide, crimes against humanity, or war crimes on the territory of a state party, and where the state of nationality (among others) is found unwilling or unable to proceed genuinely against the individual, ${ }^{8}$ has not so far been considered sufficiently reassuring. For the states that have ratified or that are moving toward ratification of the Rome Statute, the jurisdictional scheme is simply a delegation to the ICC of the territorial and national jurisdiction that states undoubtedly enjoy under international law: The ICC will do nothing more than what these states have the right to do, and only when they are unwilling or unable to do it. ${ }^{9}$ The United States argues that the possible investigation and prosecution of its nationals without its consent is tantamount to the imposition of treaty obligations on a third state-something expressly disallowed by the Vienna Convention on the Law of Treaties. ${ }^{10}$ For others, to allow the state of nationality of the accused to decide whether its nationals would be prosecuted

5. Scheffer, supra note 2, at 17.

6. See The Rome Statute, supra note 1, art. 12 (Pre-Conditions to the Exercise of Jurisdiction). Under art. 12(1), a state party accepts the court's ability to exercise jurisdiction over genocide, crimes against humanity, and war crimes. Under art. 12(2), the adherence to the statute of either the state where the crime took place (the "territorial state") or the state of nationality of the suspect or accused (the "national state") is necessary for the court to exercise its jurisdiction. Under art. 12(3), a territorial or national state that is not party to the statute may accept the court's jurisdiction ad hoc for purposes of a particular crime. Both "automatic jurisdiction" and the requirement of a territorial or national nexus were extremely contentious in the process leading to the adoption of the statute. See Elizabeth Wilmshurst, The Jurisdiction of the Court, in THE INTERNATIONAL CRIMINAL COURT, supra note 1, at 127; Sharon A. Williams, Article 12, in COMMENTARY ON THE ROME STATUTE, supra note 1, at 329.

7. See arts. $15,53,58$.

8. See arts. $17,18,19$.

9. See Kirsch \& Holmes, supra note 1 , at 1 .

10. See Scheffer, supra note 2 , at 18 . The most detailed explication, broadly sympathetic to the United States, of the legal argument is Madeline Morris, High crimes and Misconceptions: The ICC and Non-Party States, 64 LAW \& CONTEMP. PROBS. 13 (Winter 2001). For a short critique of the legality argument, see Diane F. Orentlicher, Politics by Other Means: The Law of the International Criminal Court, 32 CORNELL INT'L L.J. 489 (1999). 
would be a retreat from the Nuremberg principle that an individual cannot find immunity behind the veil of the state. ${ }^{11}$

The U.S. legal argument arises from deeper concerns. At least some (particularly military) decisionmakers are concerned that the ability of the United States to project force abroad will be constrained by possible ICC investigation into the actions of U.S. personnel on the territory either of a party to the statute or of a state consenting ad hoc to the ICC's jurisdiction. The U.S. government, in the context of an overall aim of entrenching post-Cold War U.S. preeminence in international affairs, is seeking to prevent the emergence of a possible curb on the latitude available to the U.S. military in acting as an arm of U.S. foreign policy. That such latitude might encompass actions in at least the grey zone of legality could only exacerbate this concern. ${ }^{12}$

The aim of post-Rome U.S. efforts has been to raise the comfort level of ICC skeptics within the U.S. government, in particular by limiting the court's effective powers with respect to non-party states. In its extreme (and currently favored) form, this exercise seeks a "fix" in the form of a "magic bullet" proposal that would resolve concerns through a de facto or de lege amendment to the Rome Statute. At the same time, there appears to have been debate within the relevant agencies of government as to what would constitute adequate protection with respect to which concerns. Intimately tied to this debate has been the question of the legal form such a fix should take. If " $100 \%$ protection" were to be the watchword, then a protocol or an amendment to the statute would be necessary, with all the political hurdles this would present. If full protection were to entail something less than this, then a binding understanding (of the PrepCom or of the eventual Assembly of States Parties) or an addition to the Rules of Procedure and Evidence might have sufficed.

Without exploring in detail the policies and institutional interests behind U.S. efforts, the remainder of this essay will examine the search for an accommodation of U.S. concerns in the context of the dynamics of the PrepCom to the end of the June 2000 session. In light of this analysis, the conclusion will argue that the search for a legal fix is inevitably quixotic and that early reconciliation with the ICC would best serve U.S. interests.

11. See Orentlicher, supra note 10 , at 490-95.

12. See, e.g., Jules Lobel \& Michael Ratner, Bypassing the Security Council: Ambiguous Authorizations to Use Force, Cease-fires and the Iraqi Inspection Regime, 93 A.J.I.L. 124 (1999); Bruno Simma, NATO, the U.N. and the Use of Force: Legal Aspects, 10 E.J.I.L. 1 (1999). The place of the ICC in the geopolitical framework of U.S. interests at the end of the 20th century has, to the knowledge of this author, not been adequately explored to date. But see A World Court for Criminals, ECONOMIST, Oct. 9, 1999, at 19 (arguing that U.S. opposition to the court is contrary to its larger interest in world order); Wedgwood, supra note 4 (taking a sympathetic view of U.S. concerns). For more general views finding an overriding U.S. interest in multilateralism, see America's World, ECONOMIST, Oct. 23, 1999, and Sherle R. Schwenninger, World Order Lost: American Foreign Policy in the Post-Cold War World, WORLD POL'Y J. 42 (Summer 1999). 
III

\section{CONSTRAINTS ON THE U.S. SEARCH FOR A NEGOTIATED "FIX"}

Any U.S. proposal or proposals would have to receive support from a controlling number of states engaged in the ICC process. The United States would have to create a common understanding of the problem as well as a sympathy toward its position from at least key leaders among the states involved. This raises questions as to limits set by the international situation and by positions taken by those countries that would have to agree to any accommodation.

At the time of writing, there are 114 signatories and twenty-one ratifications to the Rome Statute. ${ }^{13}$ By the end of the year 2000, a majority of the fifteen member states of the European Union are expected to have ratified the statute. Adherence to the statute by these states will secure for the court the political leadership and financial viability that others are looking for as a precondition to their own support. As a result, many of the twenty-nine sub-Saharan African and the dozen Central and Eastern European states that have so far signed the statute are expected to accelerate their processes of ratification. Although predictions vary, it is safe to say that, barring any geopolitical calamity, the Rome Treaty will enter into force and the court will be established within the first decade (or even half-decade) of the new century. ${ }^{14}$ Despite sparse Asian and Middle-Eastern support, the first Assembly of States Parties is likely to include representatives from all regions of the globe.

Importantly, it is likely to include all U.S. NATO allies, with the exception of Turkey, as well as two of the five permanent members of the Security Council (France and the United Kingdom).

From the viewpoint of U.S. diplomatic efforts, the pending establishment of the Court reduces the inclination of at least signatory states to modify arrangements under the statute. The like-minded group of countries supporting the early establishment of an effective ICC has publicly affirmed its support for the integrity of the Rome Statute in Europe, the United Nations, and other fora. These countries could not be seen to retreat from this position without considerable loss of face. Signatories with significant international military commitments, like the United Kingdom and France, have decided that the statute provides adequate safeguards to meet their concerns.

Moreover, these countries were among the majority at the Diplomatic Conference that supported what amounted to universal jurisdiction for the court, ${ }^{15}$

13. Ratifications through October 18, 2000 include Belgium, Belize, Botswana, Canada, Fiji, France, Gabon, Ghana, Iceland, Italy, Lesotho, Luxembourg, Mali, New Zealand, Norway, San Marino, Senegal, Sierra Leone, Tajikistan, Trinidad and Tobago, and Venezuela.

14. The most informative and up-to-date source on signature, ratification, and implementation of the Rome Statute is found at the "Country-by-country Ratification Status Report" and "Ratification Atlas" at the web-site of the NGO Coalition for an International Criminal Court. See <http://www. iccnow.org $>$.

15. See The Proposal of the Republic of Korea, U.N. Doc. A/CONF.183/C.1/L.6, art. 8 (June 18, 1998), proposed that the court be able to exercise its jurisdiction if any of four states was party to the 
that decisively rejected the suggestion that the exercise of jurisdiction should be based on consent of the state of nationality alone, ${ }^{16}$ and that, without U.S. urging, might well have created an independent prosecutor without the constraints now seen, in particular, in Articles 15 and 18 of the statute. These states are mindful that the jurisdictional arrangement is a compromise much narrower than that favored by the large majority at Rome, and is indeed one adopted primarily to placate the United States. ${ }^{17}$ For the United States, facing resistance to any return to the debates of Rome, only a significant new argument attracting international assent or an offer of a tangible and attractive quid pro quo could move other states in its direction.

Yet it is precisely the lack of an adequate bargaining chip that has hampered U.S. efforts to date. The United States' engagement in the PrepCom sessions has given it an incentive to stay involved through the first Assembly of States Parties, making a withdrawal or opposition (the main negative incentives in U.S. hands) seem implausible. The United States has been unable to offer a promise of signature - much less of ratification - and its support for the court (whether political, financial, or diplomatic), being contingent on the changeable politics of the Executive and Congress, cannot be offered in advance. Other governments (and in particular those that can be expected to carry the main financial burden) have made the calculation that the court will be viable on the basis of their support alone-that is, without the United States. Needless to say, these countries would prefer to have U.S. financial and diplomatic resources behind the court. But with the ICC as defined by the Rome Statute a pending reality, the United States has been unable to offer anything sufficiently tangible by way of carrots or sticks to make substantial modifications seem warranted.

In addition to isolation in its concerns and uncertainty in its bargaining power, the United States has to contend with a restricted time frame. The search for accommodation is not subject to a deadline as such, but it is shaped by key dates. Any "fix" involving the Rules of Procedure and Evidence was constrained by the deadline of June 30, 2000 for completion of the draft rules. ${ }^{18}$ Later PrepCom sessions would impose similar limits on other instruments. ${ }^{19}$ The United States might hypothetically persuade the Assembly of States Parties

statute (or consented ad hoc): the territorial state, the state of nationality of the victim or of the accused, and the state with custody of the accused.

16. See Proposal of the United States of America, U.N. Doc. A/CONF.183/C.1/L.70 (July 14, 1998).

17. According to an NGO survey published a week before the end of the conference (The International Criminal Court Monitor (July 10, 1998)), 79\% of the states favoured the Korean proposal, supra note 15 .

18. See Resolution F of the Final Act, supra note 3, II 6.

19. General Assembly Resolution 54/105 provided for a two-week session in November-December 2000 for negotiations related to issues other than the Rules of Procedure and Evidence and the Elements of Crime, which occupied the bulk of the PrepCom agenda to June 30, 2000: U.N. Doc. A/Res/54/105 (1999). Given the scope of the items involved (rules of procedure of the Assembly of States Parties, financial rules and regulations, a relationship agreement between the ICC and the U.N., and more), further sessions in 2001 will be necessary. 
to support a proposal in its favor at any time, raising the possibility that the search for a "fix" will resurface from time to time in that forum. Nonetheless, the PrepCom presents the most likely opportunity for the United States.

\section{THE PROBLEM WITH A "FIX"}

The United States has been unsuccessful in its attempt to find accommodation for a mix of formal and substantive reasons. Formally, the degree of insulation available would be highest with an amendment or a protocol to the statute. $^{20}$ The argument challenging the legality of the statute was intended in large measure to prepare the ground for such a remedy. The degree of sustained political support needed for the argument and the political cost for the likeminded countries of entering into any apparent retreat from their position of support for the integrity of the statute have led the United States to abandon this option in favor of "softer" ones. ${ }^{21}$

Substantively, the U.S. aim of preventing prosecution of its nationals abroad raises fundamental problems that have plagued U.S. attempts to win support. In essence, this is because other governments are not inclined and can see no compelling reason of principle to make a pure exception for the United States alone. At the same time, no principled general accommodation has presented itself that would meet the needs of the United States without opening a loophole through which myriad injustices would flow.

The U.S. delegation at the March 2000 PrepCom circulated an informal proposal that illustrates well problems that arise with attempts to find accommodation for its concerns. ${ }^{22}$ The proposal would prevent the court from proceeding where the national of a non-party is involved, and the state of nationality acknowledges that the individual was acting under its "overall direction," unless (1) the state of nationality consents or (2) the Security Council passes a resolution against the directing state under Chapter VII of the Charter, author-

20. Substantive amendments require the affirmative vote of two-thirds of the Assembly of States Parties, followed by ratification by seven-eighths of them, creating a very high threshold for changing the statute. See art. 121(5). A protocol to the statute would presumably require signature and ratification by all states parties.

21. During the November-December 1999 and March 2000 sessions of the PrepCom, the U.S. delegation placed less emphasis on the argument of legality than it had done previously. This appears to have been for tactical reasons, as states supportive of the court might be less inclined to make concessions to the United States in negotiations if they felt that to do so would be to concede the argument that the jurisdictional principles embedded in the Rome Statute-which they find clear and acceptable-somehow contravened the international law of treaties. The United States has not conceded the Rome Statute's legality, however, and would be likely to raise this issue if the Court were ever to indict a U.S. national.

22. Formally, the proposal has two parts. The substance of the proposal would be in the Relationship Agreement between the U.N. and the ICC, to be negotiated at the November-December PrepCom. A rule of procedure was also proposed to make clear that the Relationship Agreement would be considered an international agreement for purposes of Art. 98(1), which exempts states from their obligation to surrender an individual to the ICC in case of conflicting obligations. Article 98(1) was intended to make allowance for Status of Forces Agreements or SOFAs. See supra note 28 and accompanying text. 
izing the continuation of proceedings. While the proposal would stop the court only at the stage of surrender, and differs from past efforts in that respect, the three key features of this proposal are bound to raise familiar difficulties.

First, the threshold requirement that the state of nationality of the accused acknowledge its "overall direction" of the individual is in essence the same "official acts" exception that was proposed by the United States and subsequently rejected at Rome. ${ }^{23}$ The requirement that a non-party state acknowledge that an individual was engaged in official acts is intended to confine the exception to situations in which a state was willing so to acknowledge. However, the proposal would allow states to block ICC jurisdiction over their nationals (and for the most serious crimes conceivable), would do so when those crimes were allegedly committed on the territory of a state party to the statute (which would normally itself be able to exercise jurisdiction), would not require the state of nationality to investigate or prosecute itself, and would provide no effective control to ensure that the acknowledgement was made in good faith. For many of those who rejected this concept at Rome, it would be a clear retreat from the Nuremberg principles to allow the state of a person accused of genocide, crimes against humanity, or war crimes to block proceedings in this way. ${ }^{24}$ The second feature of the proposal, state of nationality consent, raises the same objection and was similarly rejected at Rome.

The third key feature, that of Security Council approval, revisits the position advanced by the United States through the early stages of the Rome Conference. ${ }^{25}$ Whatever the value of arguments about the priority due to the Security Council in its actions to maintain or restore international peace and security under Chapter VII of the Charter, the granting of control over court proceedings to the Security Council has been strongly resisted. Such control would allow inequitable protection of the nationals of permanent members of the Council (as well as the nationals of their proxy and client states), and has thus been criticised for institutionalizing inequality before the law. This is inflamed by the North-South issues heaped on this critique by members of the Non-Aligned Movement and others. Given that the issue of Security Council control was debated and settled at Rome, bestowing upon the Council a right to delay court

23. Proposal of the United States of America, U.N. Doc. A/CONF.183/C.1/L.90, art. 7 (July 16, 1998).

24. See Nuremberg Charter; Charter of the International Military Tribunal, Annex to the Agreement for the Prosecution \& Punishment of Major War Criminals of the European Axis, London, Aug. 8, 1945, arts. 7-8, 82 U.N.T.S. 279, reprinted in (1945) A.J.I.L. (Supp.) 257; see also Principles of International Law Recognised in the Charter of the Nuremberg Tribunal and in the Judgment of the Tribunal: Report of the International Law Commission, princs. 3-4, 5 U.N. GAOR, 2nd Sess., Supp. No. 12, U.N. Doc.. A/1316 at 11 (1950).

25. The analogy is not exact, since the March 2000 proposal would require Security Council approval only once the court was to seek surrender of the accused, rather than prevent proceedings from the start. The proposal is also narrower than the previous position, in that it would require a Security Council resolution taking measures against the state of nationality as a precondition to the surrender of nationals of that state to the court. Proceedings could continue as prescribed by the statute with respect to nationals of e.g. the state on the territory of which the crime was alleged. 
proceedings, ${ }^{26}$ the United States' ability to win support to revisit this issue has been far from sufficient. ${ }^{27}$

Despite these shortcomings, the adoption of a Rule of Procedure ${ }^{28}$ seen by the United States as laying the foundation for further negotiation toward an exemption at the November-December PrepCom ensures that this issue will be pursued, in spite of the slim prospects for success. ${ }^{29}$

\section{$\mathrm{V}$}

\section{THE ARGUMENT FOR U.S. SUPPORT}

If a full "fix" for the United States is unlikely to succeed on the ground that it would amount to a re-opening of the statute or a reversal of the "Nuremberg precedent," the United States will have to recognize that it must content itself not with a single "fix," but with a mosaic of provisions in the Rules, Elements of Crimes, and other PrepCom texts. Although possible exposure to the court's jurisdiction (at least in principle, and to a greater or lesser degree) will not have changed, these will leave the United States with more reassurance than it had after adoption of the statute.

Such exposure to ICC jurisdiction is not incompatible with U.S. support for the ICC. The institutional interest of the Defence Department in preserving its latitude as U.S. foreign policy's enforcer of last resort in the post-Cold War environment makes its opposition to the ICC rational from its own institutional point of view. However, this is only one of several U.S. interests. If one accepts that the ICC is going to come into existence and is going to do so in a form that leaves a degree of U.S. exposure to its jurisdiction, and acceptance of these propositions is increasingly unavoidable, U.S. opposition to the court becomes questionable as a possible stance, even if it could emerge in time to make a significant difference (which is highly doubtful). Such a stance would be difficult to maintain and would entail significant disadvantages for the United States.

PrepCom negotiations offer the United States an opportunity to introduce clarity, safeguards, and sometimes restrictions on the court's powers. Opposi-

26. See The Rome Statute, ch. VII res. (art. 16).

27. At the June 2000 PrepCom, Ambassador Scheffer recognized concerns raised by the Security Council's role in the U.S. proposal, and has indicated that the proposal may undergo modifications in this respect. No modified proposal had formally appeared at the time of writing.

28. Rule 9.19 states as follows: "The Court may not proceed with a request for the surrender of a person without the consent of the sending [s]tate if, under article 98, paragraph 2, such a request would be inconsistent with obligations under an international agreement pursuant to which the consent of a sending [s]tate is required prior to the surrender of a person of that State to the Court." Draft Rules, supra note 3 .

29. Delegates at the June PrepCom were careful to insert language in the final report of the session indicating that adoption of Rule 9.19 did not entail any concession of substance. An "Understanding in connection with Rule 9.19 for incorporation into the proceedings of the Preparatory Commission" reads as follows: "It is generally understood that Rule 9.19 should not be interpreted as requiring or in any way calling for the negotiation of provisions in any particular international agreement by the [c] ourt or by any other international organization or [s]tate." A number of delegates also indicated privately that it was their intention to keep the United States engaged in the process for as long as possible, without ultimately conceding any exemption. 
tion or withdrawal would eliminate the United States' ability to take advantage of this, not just with respect to the Rules of Procedure and Evidence and the Elements of Crime, but also with respect to other instruments yet to be negotiated, including the definition of aggression. Withdrawal would reduce U.S. leverage in the eventual Assembly of States Parties to prevent adverse amendment of text introduced in its favor. Opposition would multiply this effect, making adverse revision by the Assembly all the more likely. It would also contribute to a general perception that the United States was in some way opposed to the rule of law or to accountability for the worst violations of human rights. Further, the value of opposing the court must be weighed against the likelihood of its having the desired effect (of preventing the statute's entry into force). In fact, the process of ratification is too far advanced for the United States to retard it seriously, and the costs of withdrawal are too great for the United States to bear without serious reason to believe it could accomplish something thereby. The best conclusion is that the United States has gained too much both during and after Rome to step out of this process.

The most compelling reason for rejecting an all or nothing approach to a U.S. "fix" is the near inevitability of U.S. support for the ICC. For some State Department planners, eventual U.S. support or, at least, eventual U.S. ability to avail itself of the court must have a certain appeal. When the next Kosovo, East Timor, Rwanda, or Sierra Leone erupts on the international stage, will the United States refuse to support accountability merely because the ICC is the only viable means of obtaining it? For that it certainly will be. Future ad hoc tribunals, already considered unlikely, will be even less likely with France and the United Kingdom as parties to the Rome Statute, which offers structure for accepting Security Council referrals without the cost of establishing new tribunals. Even were the United States to resist the temptation to acquiesce in a Security Council referral, and instead relied on its veto, proprio motu actions by the prosecutor and state referrals might still "arise." Where the crime was egregious and the public clamour for justice significant, could the United States resist calls to provide diplomatic or other support and let its allies take the credit for promoting accountability? This seems unlikely. It is far more likely that a future U.S. government will see the political advantage in supporting a prosecution in the court, if only as a matter of raw political calculation. ${ }^{30}$

Other states involved in the process recognize the substantial reasons for eventual U.S. support for the Court. This does not mean that bona fide efforts

30. The U.S. Government itself now acknowledges this. In remarks before the House International Relations Committee on 26 July 2000, Ambassador David Scheffer stated:

We anticipate there will be instances in which it will be in the national interest to respond to requests for cooperation even if the United States is not a party to the ICC Treaty. We may decide that an international investigation and prosecution of a Pol Pot, a Saddam Hussein, an Idi Amin, a Foday Sankoh, or some other rogue leader . . . would be in the national interest of the United States to support.

Transcript of Remarks at 2 (on file with the author). 
will not be made to increase the "comfort level" of the United States ${ }^{31}$-it only means that states see little reason to weaken a court that the United States is unlikely to oppose and has a number of good reasons to support. ${ }^{32}$

VI

\section{CONCLUSION}

At present, the United States is bound up in more than a debate about the jurisdiction of the court. It is caught up in a series of processes that will ultimately shape the U.S. role in the geopolitical environment of the twenty-first century. The respective values of multilateralism and unilateralism, of isolationism and the support for an infrastructure of global governance, of "soft power" and the role of the military, are all under debate. This is unfortunate, as the ICC itself has at best an ambiguous place in these larger debates and is to some extent held hostage by them. The long-term U.S. interest in international justice would by itself clearly dictate early and sustained U.S. support for the ICC, even—and arguably especially—without the much sought-after "fix."

Over the course of 2000 and 2001, the United States will have to take a series of decisions. These decisions will not foreclose efforts by the United States to ensure that the ICC operates to the extent possible in conformity with U.S. priorities and with sensitivity to U.S. interests. They should, however, allow the ICC to become an accepted part of U.S. foreign policy discourse, and by so doing remove one impediment to coherence in the views of justice and accountability.

While U.S. concerns are not irrational, as such, they are unlikely to be satisfied through PrepCom negotiations. Rather, the United States will probably have to content itself with making its concerns known, and then by responding on a case-by-case basis in the unlikely event that investigation of U.S. personnel should arise. Meanwhile, the United States would be undermining its own interests by insisting on insulation of its personnel as the price for its toleration or support for the ICC. Rather, the United States ought, in its own interest, to lay the foundations for eventually supporting the court, notwithstanding the potential (albeit remote) risk of investigation of its nationals. While defence interests

31. For example, one like-minded government has privately suggested an extension of Article 124 of the statute to non-party states. Article 124 allows states, upon becoming party to the statute, to declare for up to seven years that they do not accept the court's jurisdiction over war crimes. Extending this to non-parties would give the United States until approximately 2010 to watch the development of the ICC before deciding what stance to take. The proposal has not been pursued, however, as it appears to fall too far below the benchmarks for "protection" that the United States has set for itself. See Diane F. Orentlicher, International Criminal Tribunals: An Institution the United States Can Support, unpublished paper presented at America's National Interests in Multilateral Engagement: A Bipartisan Dialogue, at John F. Kennedy School of Government, Harvard University, May 14-15, 2000 (on file with the author).

32. Canadian Foreign Minister Lloyd Axworthy made this clear when he stated: "Let's continue to work and massage and accommodate .... But there has to be flexibility on the U.S. side. They have to adjust their sights now too and recognize that they are not going to get an exemption from this court." Barbara Crossette, U.S. Resists War-Crimes Court as Canada Conforms, N.Y. TIMES, July 22, 2000, at A4. 
would promote their own agenda as they have, the U.S. interest in the court dictates that the Executive resolve conflict between agency interests by putting the long-term, broad U.S. interest firmly at the center of its foreign policy. Signature of the Rome Statute would be one expression of this approach. 